\title{
Встановлення кореляційної залежності засвоєння базових вправ спортивної акробатики від використання окремих спеціально-підготовчих вправ юних акробатів-початківців 6-7 років
}

Тетяна Черних
Вячеслав Мулик
Харківська державна академія фізичної культури,

Харків, Україна

Мета: визначити кореляційний взаємозв'язок базових вправ початкової підготовки юних акробатів та спеціально-підготовчих вправ, що використовуються для їх засвоєння.

Матеріал і методи: дослідження проводилося на базі комплексної дитячо-юнацької спортивної школи № 6 Слобідського району м. Харкова. У дослідженні брали участь 14 дітей 6-7 років, які займалися спортивною акробатикою у спортивно-оздоровчих групах, на участь яких було отримано згоду батьків. На початку дослідження, після ознайомчих занять, було проведено контрольне тестування виконання базових вправ «ластівка», «перекид вперед», «колесо», «берізка», «місток», після чого проведено підготовчий етап (20 занять) з використанням спеціально-підготовчих вправ для розвитку рухових якостей, необхідних для виконання зазначених базових вправ та проведено повторне тестування, оцінка якого здійснювалася за 10-бальною шкалою. Після цього проведено кореляційний аналіз залежності базових акробатичних вправ від спеціально-підготовчих вправ, які використовувалися для їх виконання.

Результати: у процесі використання комплексів спеціально-підготовчих вправ підвищилась якість виконання базових вправ за рахунок використання спеціально-підготовчих вправ у вправі «ластівка» $(t=3,94 ; p<0,001)$, «перекид вперед» $(t=2,90 ; p<0,05)$, «колесо» $(t=2,12 ; p>0,05)$, «берізка» $(t=2,67 ; p<0,05)$, «місток» $(t=2,59 ; p<0,05)$.

Висновки: у результаті досліджень встановлено кореляційний взаємозв'язок базових акробатичних вправ 3 окремими спеціально-підготовчими вправами, які використовуються під час їх навчання.

\section{Ключові слова: базові акробатичні вправи, юні акробати, кореляція.}

\section{Вступ}

На етапі початкової підготовки у процесі навчання основним є засвоєння найпростіших елементів акробатики, які у подальшому удосконалюються, засвоюються більш складні елементи, що поєднуються у змагальні композиції $[12,13,14]$.

У той же час у юного спортсмена закладається різностороння технічна база, що сприяє оволодінню широким комплексом різноманітних рухових дій $[1,7,9]$. Такий підхід $€$ основою для подальшого технічного вдосконалення. Це положення розповсюджується і на подальші базові етапи багаторічної підготовки, проте, особливо необхідно враховувати його в період початкової підготовки [3, 4, 8, 10].

При засвоєнні базових елементів спортивної акробатики важливе значення має сполучення в одному навчально-тренувальному занятті, як окремих акробатичних вправ, так і спеціально-підготовчих вправ для їх формування [11]. Існують декілька підходів щодо побудови навчальних занять: в одному занятті вирішувати завдання щодо засвоєння окремої базової вправи спортивної акробатки; в одному занятті засвоювати дві базові вправи, які близькі за структурою рухів (наприклад, «берізка» i «місток»), в яких рекомендують спеціально-підготовчи вправи, наприклад, «місток з упору на плечі»); в одному занятті послідовно засвоювати спочатку менш складні базові вправи з поступовим їх ускладненням спеціальними вправами [5, 6, 14].

Тому при плануванні навчальних занять дуже важливим $€$ врахування впливу окремих фізичних вправ на формування базових елементів спортивної акробатики у юних спортсменів 6-7 років.

Мета дослідження - визначити кореляційний взаємозв'язок базових вправ початкової підготовки юних акробатів та спеціально-підготовчих вправ, що використовуються для їх засвоєння.

\section{Матеріал і методи дослідження}

Дослідження проводилися у 2 етапи. На першому визначався комплексний вплив спеціально-підготовчих вправ на окремі базові вправи спортивної акробатики. На другому - встановлювалася кореляція між базовими акробатичними вправами та спеціально-підготовчими вправами, що сприяють засвоєнню техніки їх виконання.

\section{Результати дослідження}

Результати проведеного дослідження на першому етапі представлено у таблиці 1. 
Таблиця 1

Вплив спеціально-підготовчих вправ для засвоєння базових вправ спортивної акробатиці на етапі початкової підготовки, $\mathrm{x} \pm \mathrm{m} ; \mathrm{n} 1=\mathrm{n} 2=14$

\begin{tabular}{|c|c|c|c|c|c|}
\hline Вправа & $\begin{array}{c}\text { На } \\
\text { початок }\end{array}$ & Спеціально-підготовчі вправи & $\begin{array}{c}\text { На } \\
\text { кінець }\end{array}$ & $\mathrm{t}$ & $\mathrm{p}$ \\
\hline «Ластівка» & $4,8 \pm 0,22$ & $\begin{array}{l}\text {-стоячи обличчям до } \\
\text { гімнастичної стійки, махи ногою; } \\
\text {-утримання рівноваги на одній } \\
\text { нозі до гімнастичної стійки; } \\
\text { - рівновага, самостійно } \\
\text { утримувати від 3-4 с до 10-12 с; } \\
\text { - виконувати рівновагу із } \\
\text { закритими очима }\end{array}$ & $6,1 \pm 0,24$ & 3,94 & $<0,001$ \\
\hline $\begin{array}{c}\text { «ерекид } \\
\text { вперед» }\end{array}$ & $4,2 \pm 0,20$ & $\begin{array}{l}\text {-перекати вперед і назад у } \\
\text { групуванні, лежачи на спині; } \\
\text {-сидячи у групуванні, перекат } \\
\text { назад і вперед, відштовхуючись } \\
\text { руками біля голови; } \\
\text {-в упорі у положенні присіду, } \\
\text { згинання рук і нахили голови до } \\
\text { торкання потилицею підлоги }\end{array}$ & $5,1 \pm 0,23$ & 2,90 & $<0,05$ \\
\hline «Колесо» & $3,6 \pm 0,22$ & $\begin{array}{l}\text {-присідання,стрибки, } \\
\text { розтяжки під час розминки; } \\
\text {-стійка на руках у стіни; } \\
\text {-бокова стійка; } \\
\text {-повороти на } 360^{\circ} ; \\
\text {-перестрибування з ноги на ногу } \\
\text { у стійці «трикутником» }\end{array}$ & $4,3 \pm 0,24$ & 2,12 & $>0,05$ \\
\hline «Берізка» & $4,0 \pm 0,20$ & $\begin{array}{l}\text {-нахили голови в сторони, } \\
\text { вперед, назад; } \\
\text {-згинання-розгинання рук в упорі } \\
\text { лежачи на підлозі; } \\
\text {-максимальні нахили тулуба } \\
\text { вперед; } \\
\text {-присідання до паралельного } \\
\text { положення стегна щодо підлоги; } \\
\text {-згинання ніг у колінних } \\
\text { суглобах, лежачи на спині }\end{array}$ & $4,8 \pm 0,22$ & 2,67 & $<0,05$ \\
\hline «Місток» & $4,2 \pm 0,21$ & $\begin{array}{l}\text {-місток з упору на плечі; } \\
\text {-«зворотня планка»; } \\
\text {-вхід в місток з гімнастичної } \\
\text { лави; } \\
\text {-напівмісток; } \\
\text {-вхід в місток з опорою по стінці }\end{array}$ & $5,0 \pm 0,28$ & 2,59 & $<0,05$ \\
\hline
\end{tabular}

Оцінка виконання вправ здійснювалася за 10-бальною шкалою зі зниженням: дрібні помилки - 0,1 бала, значні помилки - 0,2-0,3 бали, грубі помилки - 0,5 бала, падіння - 1,0 бал [11].
Усі статичні індивідуальні елементи повинні витримуватись 2 секунди.

За кожну недотриману секунду під час виконання індивідуального етапного елементу знімається 0,3 бала. 


\section{Матриця кореляційної залежності спеціально-підготовчих вправ та виконання базової акробатичної вправи «ластівка»}

\begin{tabular}{|c|l|c|}
\hline $\begin{array}{c}\text { No } \\
\text { 3/p }\end{array}$ & \multicolumn{1}{|c|}{ Вправи } & \multicolumn{1}{|c|}{ Коефіцієнт кореляції } \\
\hline 1 & Стоячи обличчям до гімнастичної стійки, махи ногою & 0,42 \\
\hline 2 & $\begin{array}{l}\text { Утримання рівноваги, стоячи на одній нозі до } \\
\text { гімнастичної стінки }\end{array}$ & 0,56 \\
\hline 3 & $\begin{array}{l}\text { Утримання рівноваги на одній нозі від 3-4 с до 10-12 } \\
\text { с }\end{array}$ & 0,64 \\
\hline 4 & $\begin{array}{l}\text { Виконання рівноваги на двох ногах із закритими } \\
\text { очима }\end{array}$ & 0,48 \\
\hline 5 & $\begin{array}{l}\text { Виконання рівноваги на одній нозі із закритими } \\
\text { очима }\end{array}$ & 0,60 \\
\hline
\end{tabular}

За умови фіксації індивідуального елемента менше за 1 секунду - знімається його оцінка.

Отримані результати свідчать про ефективність розробленої і впровадженої методики використання різних спеціально-підготовчих вправ для засвоєння базових елементів спортивної акробатики на початковому етапі навчання.

Слід зауважити про неоднаковий вплив використаних комплексів вправ. Так, в цілому, на більш простіші вправи суттєво вплинуло використання експериментальної методики застосування спеціальних вправ: виконання «ластівки» покращилося на 1,3 бали $(\mathrm{t}=3,94$; $\mathrm{p}<0,001)$, «перекиду вперед» - на 0,9 бали ( $\mathrm{t}=2,90$; $\mathrm{p}<0,05)$, «берізки» - на 0,8 бали (t=2,67; $\mathrm{p}<0,05)$, «містка» - на 0,8 бали ( $t=2,59 ; \mathrm{p}<0,05)$. У свою чергу, на виконання найбільш складної вправи, «колесо», у меншій мірі вплинули (t=2,12; p>0,005) спеціально-підготовчі вправи, що потребує подальшого їх застосування. Поряд з цим важливо визначити ефективність вправ, які впливають на виконання базових елементів, що дасть можливість використовувати саме ті, що за своєю структурою рухів та динамікою їх виконання найбільш відповідають базовій вправі. Зазначене особливо стосується найбільш складних за динамічною структурою рухів, що, перш за все, стосується базової вправи на початковому етапі підготовки - «колесо».

У зв'язку з чим, нами проведено кореляційний аналіз ефективності використання спеціальних вправ, що використовувалися під час початкового навчання для засвоєння базових елементів спортивної акробатики.
Як свідчать отримані результати, найбільш ефективною $є$ вправа утримання рівноваги, стоячи на одній нозі тривалий час (до 10-12 с) та утримання рівноваги 3 закритими очима на одній нозі $(r=0,60)$ як такі, що найбільш відповідають за структурою рухів вправі «ластівка» (табл.2).

У той же час зазначені спеціальні вправи є найбільш складними у виконанні, тому вони повинні використовуватися після застосування інших, менш складних (махи ногами, стоячи обличчям до гімнастичної стійки; утримання рівноваги, стоячи на одній нозі до гімнастичної стійки; виконання рівноваги на двох ногах із закритими очима).

Вправи, що використовуються при засвоєнні перекиду вперед» $€$ ефективними, так як кореляційний зв'язок $є$ на рівні середнього $(r=0,50-0,60)$ : перекати вперед і назад у групуванні, лежачи на спині $є$ складовою частиною зазначеної базової вправи на початковому етапі ( $r=60)$ (табл. 3).

Першою може використовуватися вправа, пов'язана з фіксацією вихідного положення в упорі з присіду, згинання рук і нахили голови до торкання потилицею підлоги, а потім здійснювати перекати вперед і назад.

Важливою та найбільш складною у виконанні є базова вправа «колесо», яка потребує прояву динаміки рухів зі зміною положень частин тіла у просторі. Тому найбільш значущими елементами $є$ ті, що дозволяють здійснювати фіксацію стійки на руках біля стіни $(r=0,60)$ (табл. 4).

Таблиця 3

Матриця кореляційної залежності спеціально-підготовчих вправ та виконання базової акробатичної вправи «перекид вперед»

\begin{tabular}{|c|c|c|}
\hline $\begin{array}{l}\text { № } \\
\text { 3/p }\end{array}$ & Вправи & Коефіціснт кореляції \\
\hline 1 & Перекати вперед і назад у групуванні, лежачи на спині & 0,60 \\
\hline 2 & $\begin{array}{l}\text { Перекат назад і вперед, сидячи у групуванні, } \\
\text { відштовхуючись руками біля голови }\end{array}$ & 0,58 \\
\hline 3 & $\begin{array}{l}\text { В упорі у положенні присіду, згинання рук і нахили } \\
\text { голови до торкання потилицею підлоги }\end{array}$ & 0,50 \\
\hline
\end{tabular}




\section{СЛОБОЖАНСЬКИЙ НАУКОВО-СПОРТИВНИЙ ВІСНИК}

Таблиця 4

Матриця кореляційної залежності спеціально-підготовчих вправ та виконання базової акробатичної вправи «колесо»

\begin{tabular}{|l|l|c|}
\hline $\begin{array}{r}\text { No } \\
\text { 3/p }\end{array}$ & \multicolumn{1}{|c|}{ Вправи } & Коефіціснт кореляції \\
\hline 1 & Присідання, стрибки, розтяжки під час розминки & 0,41 \\
\hline 2 & Стійка на руках біля стіни & 0,61 \\
\hline 3 & Бокова стійка & 0,60 \\
\hline 4 & Повороти на 360 & 0,58 \\
\hline 5 & $\begin{array}{l}\text { Перестрибування 3 ноги на ногу у стійці } \\
\text { «трикутником» }\end{array}$ & 0,56 \\
\hline
\end{tabular}

У свою чергу, важливою є вправа, пов'язана з просторовою орієнтацією за участю вестибулярного аналізатора зі зміною положення тіла спортсмена.

Виконання базової акробатичної вправи «берізка» потребує залучення м'язів живота до приведення ніг 3 горизонтального положення у вертикальне, тому найбільш ефективним $€$ використання спеціально-підготовчої вправи «згинання ніг у колінних суглобах, лежачи на спині» $(r=0,58)$ та «піднімання ніг, сидячи на лавці» $(r=0,65)$ (табл.5).

Важливим також є утримання положення «берізка», для цього потрібний значний рівень силових якостей верхніх кінцівок, чому сприяє використання спеціальнопідготовчої вправи «згинання-розгинання рук в упорі лежачи» $(r=0,52)$.

Вправи, що застосовувалися для засвоєння базового елемента спортивної акробатики «місток», передбачають рухові дії для здійснення виходу у виконання вправи та утримання пози (окремих її складових) у статичному положенні (табл. 6).

Всі спеціальні вправи мають суттєве значення для формування окремих складових базової вправи «місток» 3 опорою по стінці $(r=0,64)$ та «вхід в місток $з$ гімнастичної лави» $(r=0,60)$.

Таблиця 5

Матриця кореляційної залежності спеціально-підготовчих вправ та виконання базової акробатичної вправи «берізка»

\begin{tabular}{|l|l|l|}
\hline $\begin{array}{c}\text { № } \\
\mathbf{3} / \mathbf{p}\end{array}$ & \multicolumn{1}{|c|}{ Вправи } & Коефіціснт кореляції \\
\hline 1 & Нахили голови в сторони, вперед, назад & 0,32 \\
\hline 2 & Згинання-розгинання рук в упорі лежачи на підлозі & 0,52 \\
\hline 3 & Максимальні нахили тулуба вперед & 0,48 \\
\hline 4 & $\begin{array}{l}\text { Присідання до паралельного положення стегна щодо } \\
\text { підлоги }\end{array}$ & 0,49 \\
\hline 5 & Згинання ніг у колінних суглобах, лежачи на спині & 0,58 \\
\hline 6 & Піднімання ніг, сидячи на лавці & 0,65 \\
\hline
\end{tabular}

Таблиця 6

Матриця кореляційної залежності спеціально-підготовчих вправ та виконання базової акробатичної вправи «місток»

\begin{tabular}{|l|l|l|}
\hline $\begin{array}{c}\text { № } \\
\text { 3/p }\end{array}$ & \multicolumn{1}{|c|}{ Вправи } & \multicolumn{1}{|c|}{ Коефіціснт кореляції } \\
\hline 1 & «Місток» 3 упору на плечі & 0,56 \\
\hline 2 & «Зворотня планка» & 0,54 \\
\hline 3 & Вхід в місток 3 гімнастичної лави & 0,60 \\
\hline 4 & «Напівмісток» & 0,58 \\
\hline 5 & Вхід в «місток» з опорою по стінці & 0,64 \\
\hline
\end{tabular}




\section{Висновки / Дискусія}

Засвоєння базових елементів акробатики у юних спортсменів потребує певного рівня розвитку рухових якостей, що забезпечують їх виконання [14]. у той же час ефективність використання спеціально-підготовчих вправ залежить від структури їх рухів для виконання базової вправи [2]. Тому слід мати на увазі, що використання спеціальних вправ повинно передбачати можливість у значній мірі сприяти формуванню рухових якостей, спрямованих на ефективність структури виконання базових акробатичних вправ.

Проведені нами дослідження дозволили:

1. Визначити вплив застосування комплексів спеціально-підготовчих вправ на якість виконання базових акробатичних вправ юних акробатів 6-7 років, які дозволили підвищити оцінку у вправах «ластівка» на 1,3 бали $(t=3,94 ; p<0,001)$, «перекид вперед» на 0,9 бали ( $t=2,90$; $\mathrm{p}<0,05)$, «берізка» на 0,8 бали ( $t=2,67 ; \mathrm{p}<0,05)$, «місток» на 0,8 бали ( $t=2,59 ; p<0,05)$.

2. Встановлено кореляційну залежність виконання базових вправ початкових занять спортивною акробатикою та спеціально-підготовчих вправ, що забезпечують виконання вправ: «ластівка» має середній рівень кореля- ції з вправами: утримання рівноваги, стоячи на одній нозі, до гімнастичної стінки $(r=0,56)$, утримання рівноваги на одній нозі від 3-4c до 10-12с ( $r=0,64)$, виконання рівноваги на одній нозі із закритими очима $(r=0,60)$; «перекид вперед» з перекатом вперед і назад у групуванні, лежачи на спині $(r=0,60)$; перекат назад і вперед, сидячи у групуванні, відштовхуючись руками біля голови $(r=0,58)$; в упорі у положенні присіду, згинання рук і нахили голови до торкання потилицею підлоги $(r=0,50)$; «колесо» з стійкою на руках у стіни $(r=0,61)$, «бокова стійка» $(r=0,60)$, повороти на $360^{\circ}(r=0,58)$, перестрибування з ноги на ногу у стійці «трикутником» $(r=0,56)$; «берізка» із згинаннямрозгинанням рук в упорі лежачи на підлозі $(r=0,52)$, згинання ніг у колінних суглобах, лежачи на спині $(r=0,58)$, піднімання ніг, сидячи на лавці $(r=0,65)$; «місток» 3 містком з упору на плечі $(r=0,56)$, «зворотна планка» $(r=0,54)$, вхід в «місток» із гімнастичної лави $(r=0,60)$, «напівмісток» $(r=0,58)$, вхід в «місток» $з$ опорою по стінці $(r=0,64)$.

Перспективи подальших досліджень. Отримані результати дають можливість цілеспрямовано використовувати окремі спеціально-підготовчи вправи при побудові навчання базовим акробатичним вправам у юних спортсменів-початківців.

Конфлікт інтересів. Автори заявляють, що немає конфлікту інтересів, який може сприйматися як такий, що може завдати шкоди неупередженості статті.

Джерела фінансування. Ця стаття не отримала фінансової підтримки від державної, громадської або комерційної організації.

\section{Список посилань}

1. Болобан В. Н. (1988), «Методика отбора детей для занятий акробатикой», Спортивная акробатика. Выща школа, Киев, C. 59-64.

2. Бернштейн Н. А. (1991), О ловкости и ее развитии. Москва: Физкультура и спорт, 288 с.

3. Волков Л. В. (2002), Теория и методика детского и юношеского спорта. Киев: Олимпийская литература, 295 с.

4. Иссурин В. Б. (2016), Подготовка спортсменов XX1 века: научные основы и построение тренировки. Москва: Спорт, $464 \mathrm{c}$.

5. Каленская Г. А., Барбашов С.В. (2017), «Теоретическое обоснование программы хореографической подготовки юных акробатов», Вестник Югорского государственного университета. Выпуск 1 (44). С. 105-112.

6. Костюкевич В. М. (2007), Теорія і методика тренування спортсменів високої кваліфікації: навчальний посібник. Вінниця: Планер, 273 с.

7. Матвеев Л. П. (1999), Основы общей теории спорта и системы подготовки спортсменов. Киев: Олимпийская литература, 320 c.

8. Платонов В. Н., Сахновский К. П. (1988), Подготовка юного спортсмена. Киев: Радянська школа, 298 с.

9. Платонов В. Н. (2017), Двигательные качества и физическая подготовка спортсменов. Киев: Олимпийская литератуpa, $656 \mathrm{c}$.

10. Помазан А. А. (2011), «Рухові характеристики хлопчиків 4-6 років для визначення перспективності до занять гімнастикою», Педагогіка, психологія та медико-біологічні проблеми фізичного виховання і спорту. Вип. 10, С.57-60.

11. Сениця А. І., Сениця М. М., Передерій А. В. (2010), Спортивна акробатика: навчальна програма для дитячо-юнацьких спортивних шкіл. Вінниця, 92 с.

12. Черних Т., Мулик В., Скалій Т., Окунь Д. (2020), «Застосування спеціально-підготовчих вправ для засвоєння базових елементів спортивної акробатики юними спортсменами-початківцями», Слобожанський науково-спортивний вісник. №6 (80), C.11-16. doi:10.15391/snsv.2020-6.002

13. Харченко Т. П., Мулик В. В. (2009), «Дослідження надійності та інформативності тестів для визначення статичної та динамічної рівноваги в юних фігуристів 7-9 років», Слобожанський науково-спортивний вісник. Вип.3. С.82-84.

14. Черних Т., Мулик В., Окунь Д. (2019), «Дослідження рівня фізичної підготовленості юних спортсменів-акробатів на початковому етапі підготовки», Слобожанський науково-спортивний вісник. №5(73), С.61-65, doi: 10. 15391/snsv 2019-5.010

15. Taboada-Iglesias Y., Abalo R. (2018), «Lesiones en los deportes acrobaticos gimnasticos y disciplinas afines», Trances, № $10(1)$, pp. 21-44.

Стаття надійшла до редакції: 06.05.2021 p.

Опубліковано: 23.06.2021 р. 


\title{
СЛОБОЖАНСЬКИЙ НАУКОВО-СПОРТИВНИЙ ВІСНИК
}

\begin{abstract}
Аннотация. Татьяна Черных, Вячеслав Мулик. Установление корреляционной зависимости усвоения базовых упражнений спортивной акробатики от применения отдельных специально-подготовительных упражнений юных акробатов 6-7 лет. Цель: определить корреляционную взаимосвязь базовых упражнений начальной подготовки юных акробатов и специально-подготовительных упражнений, используемых для их усвоения. Материал и методы: исследование проводилось на базе комплексной детско-юношеской спортивной школы № 6 Слободского района г. Харькова. В исследовании принимали участие 14 детей 6-7 лет, которые занимались спортивной акробатикой в спортивно-оздоровительных группах, на участие которых получено согласие родителей. В начале исследования после ознакомительных занятий было проведено контрольное тестирование выполнения базовых упражнений «ласточка», «кувырок вперед», «колесо», «березка», «мостик», после чего проведено подготовительный этап (20 занятий) с использованием специально-подготовительных упражнений для развития двигательных качеств, необходимых для выполнения указанных базовых упражнений и проведено повторное тестирование, оценка которого осуществлялась по 10-балльной шкале. После этого проведен корреляционный анализ зависимости базовых акробатических упражнений от специально-подготовительных упражнений, которые использовались для их выполнения. Результаты: в процессе использования комплексов специально-подготовительных упражнений повысилось качество выполнения базовых упражнений за счет использования специально-подготовительных упражений в упражнении «ласточка» $(t=3,94 ; p<0,001)$, «кувырок вперед» $(t=2,90 ; p<0,05)$, «колесо» $(t=2,12 ; p<0,05)$, «березка» $(t=2,67 ; p<0,05)$, «мостик» $(t=2,59 ; p<0,05)$. Выводы: в результате исследований установлена корреляционная взаимосвязь базовых акробатических упражнений с отдельными специально-подготовительными упражнениями, используемых во время их обучения.
\end{abstract}

Ключевые слова: базовые акробатические упражнения, юные акробаты, корреляция.

Abstract. Tetiana Chernykh, Viacheslav Mulyk. Establishment of the correlation dependence of mastering basic exercises in sports acrobatics on the use of individual special preparatory exercises by young acrobats 6-7 years old. Purpose: to determine the correlation relationship between the basic exercises of the initial training of young acrobats and special preparatory exercises used to master them. Material and Methods: the research was carried out on the basis of the complex children's sports school No. 6, Slobodsky district of Kharkov. 14 children 6-7 years old took part in the study, they were engaged in sports acrobatics in sports and health-improving groups, for whose participation parental consent was obtained. At the beginning of the study, after introductory sessions, control testing of the basic exercises "Swallow», "forward roll», "wheel», "birch» "crab position", development of motor qualities, necessary for the fulfillment of the specified basic exercises, and repeated testing was carried out, the assessment of which was carried out on a 10-point scale. After that, a correlation analysis of the dependence of basic acrobatic exercises on special preparatory exercises that were used to perform them was carried out. Results: in the process of using complexes of special preparatory exercises, the quality of basic exercises performance was increased due to the use of special preparatory exercises in the «Swallow» exercise $(t=3,94 ; p<0,001)$, «forward roll» $(t=2,90 ; p<0,05)$, «wheel» $(t=2,12 ; p<0,05)$, «birch» $(t=2,67 ; p<0,05)$, «crab position" $(t=2,59 ; p<0,05)$. Conclusions: as a result of the research, a correlation has been established between basic acrobatic exercises and individual special preparatory exercises used during their training.

Keywords: basic acrobatic exercises, young acrobats, correlation.

\section{References}

1. Boloban, V. N. (2007), «Methods of selection of children for acrobatics», Sportivnaya akrobatika. Vyischa shkola, Kiev, pp. 59-64. (in Russ.).

2. Bernshtejn, N. A. (1991), O lovkosti i ee razvitii. [About agility and its development]. Moskva: Fizkultura i sport, 288 p. (in Russ.).

3. Volkov, L. V. (2002), Teoriia i metodika detskogo i iunosheskogo sporta [Theory and methodology of children's and youth sports]. Kiev : Olimpiiskaia literatura, 295 p. (in Russ.).

4. Issurin, V. B. (2016), Podgotovka sportsmenov XXI veka: nauchnye osnovy i postroenie trenirovki [Training of athletes of the XXI century: scientific foundations and construction of training]. Moskva: Sport, 464 p. (in Russ.).

5. Kalenskaia, G. A., Barbashov, S. V. (2017), «Theoretical substantiation of the programs of theoretical training of young acrobats», Vestnik lugorskogo gosudarstvennogo universiteta. Vypusk 1 (44), pp. 105-112. (in Russ.).

6. Kostiukevych, V. M. (2007), Teoriia i metodyka trenuvannia sportsmeniv vysokoi kvalifikatsii [Theory and methodology of training highly qualified athletes]: navchalnyi posibnyk. Vinnytsia: Planer, 273 p. (in Ukr.).

7. Matveev, L. P. (1999), Osnovy obshhej teorii sporta i sistemy podgotovki sportsmenov [Fundamentals of the general theory of sports and the system of training athletes]. Kiev: Olimpijskaja literatura, 320 p. (in Russ.).

8. Platonov, V. N., Sakhnovskii, K. P. (1988), Podgotovka iunogo sportsmena [Training of a young athlete]. Kiev : Radianska shkola, 288 p. (in Russ.).

9. Platonov, V. N. (2017), Dvigatelnye kachestva i fizicheskaia podgotovka sportsmenov [Motor qualities and physical training of athletes]. Kiev: Olimpiiskaia literatura, 656 p. (in Russ.).

10. Pomazan, A. A. (2011), "Motor characteristics of boys 4-6 years to determine the prospects for gymnastics", Pedahohika, psykholohiia ta medyko-biolohichni problemy fizychnoho vykhovannia i sportu. Vyp. 10, pp. 57-60. (in Ukr.).

11. Senytsia, A. I., Senytsia, M. M., Perederii, A. V. (2010), Sportyvna akrobatyka [Sports acrobatics]: navchalna prohrama dlia dytiacho-yunatskykh sportyvnykh shkil. Vinnytsia, 92 p. (in Ukr.).

12. Chernykh, T., Mulyk, V., Skalii, T., Okun, D. (2020), «The use of special preparatory exercises for the assimilation of the basic elements of sports acrobatics by young novice athletes», Slobozhanskyi naukovo-sportyvnyi visnyk. №6 (80), pp.11-16. doi:10.15391/ snsv.2020-6.002. (in Ukr.).

13. Kharchenko, T. P., Mulyk, V. V. (2009), «Research of reliability and informativeness of tests for definition of static and dynamic balance at young figure skaters of 7-9 years", Slobozhanskyi naukovo-sportyvnyi visnyk. Vyp. 3. pp. 82-84. (in Ukr.).

14. Chernykh, T., Mulyk, V., Okun, D. (2019), «Study of the level of physical fitness of young acrobat athletes at the initial stage of training", Slobozhanskyi naukovo-sportyvnyi visnyk, No. 5(73), pp. 61-65, doi:10.15391/snsv.2019-5.010 (in Ukr.).

15. Taboada-Iglesias Y., Abalo R. (2018), «Lesiones en los deportes acrobaticos gimnasticos y disciplinas afines», Trances, № 10(1), pp. 21-44. (in Esp.).

Received: 06.05.2021.

Published: 23.06.2021. 


\section{Відомості про авторів / Information about the Authors}

Черних Тетяна Ігорівна: аспірант кафедри олімпійського та професійного спорту; Харківська державна академія фізичної культури: 61058, м. Харків, вул. Клочківська, 99, Україна.

Черных Татьяна Игоревна: аспирант кафедры олимпийского и профессионального спорта; Харьковская государственная академия физической культуры: 61058, г. Харьков, ул. Клочковская, 99, Украина.

Tetiana Chernykh: graduate student of the Department of Olympic and Professional Sports; Kharkiv State Academy of Physical Culture: 61058, Kharkiv, st. Klochkivska, 99, Ukraine.

ORCID: https://orcid.org//0000-0003-0797-2059

E-mail: tchernish147@gmail.com

Мулик Вячеслав Володимирович: д.фіз.вих., професор; Харківська державна академія фізичної культури: вул. Клочківська 99, м. Харків, 61058, Україна.

Мулик Вячеслав Владимирович: д. физ.восп., профессор; Харьковская государственная академия физической культуры: ул. Клочковская 99, г. Харьков, 61058, Украина.

Viacheslav Mulyk: Doctor of Sciences (Physical Education and Sports), Professor; Kharkiv State Academy of Physical Culture: 61058, Kharkiv, st. Klochkivska, 99, Ukraine.

ORCID: https://orcid.org/0000-0002-4441-1253

E-mail: mulyk.viacheslav@gmail.com 